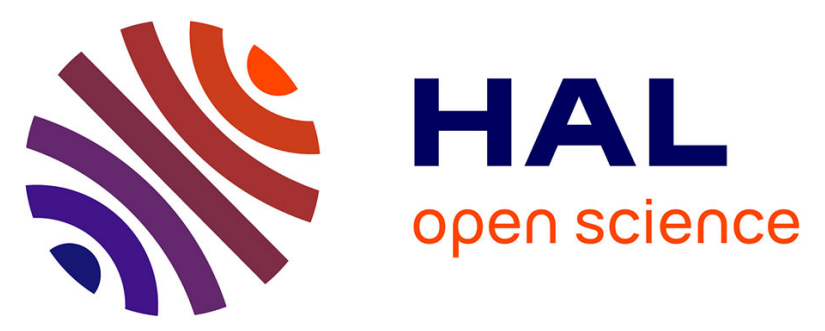

\title{
Carbon monoxide substitutions by trimethyl phosphite in diiron dithiolate complex Fe-Fe bond cleavage, selectivity of the substitutions, crystal structures and electrochemical studies
}

\author{
N.B. Makouf, H.B. Mousser, A. Darchen, A. Mousser
}

\section{To cite this version:}

N.B. Makouf, H.B. Mousser, A. Darchen, A. Mousser. Carbon monoxide substitutions by trimethyl phosphite in diiron dithiolate complex $\mathrm{Fe}-\mathrm{Fe}$ bond cleavage, selectivity of the substitutions, crystal structures and electrochemical studies. Journal of Organometallic Chemistry, 2018, 866, pp.35-42. 10.1016/j.jorganchem.2018.04.005 . hal-01809155

\section{HAL Id: hal-01809155}

https://hal-univ-rennes1.archives-ouvertes.fr/hal-01809155

Submitted on 20 Jun 2018

HAL is a multi-disciplinary open access archive for the deposit and dissemination of scientific research documents, whether they are published or not. The documents may come from teaching and research institutions in France or abroad, or from public or private research centers.
L'archive ouverte pluridisciplinaire HAL, est destinée au dépôt et à la diffusion de documents scientifiques de niveau recherche, publiés ou non, émanant des établissements d'enseignement et de recherche français ou étrangers, des laboratoires publics ou privés. 
1 Carbon monoxide substitutions by trimethyl phosphite in diiron dithiolate complex: Fe-

2 Fe bond cleavage, selectivity of the substitutions, crystal structures and electrochemical

3 studies

4 Naouel Boukrina Makouf ${ }^{1}$, Hénia Bouzidi Mousser ${ }^{1,2^{*}}$, André Darchen $^{3}$ and Abdelhamid

5 Mousser $^{1}$

$6 \quad{ }^{1}$ Laboratoire de Physicochimie Analytique et Cristallochimie de Matériaux

7 Organométalliques et Biomoléculaires, Université des Frères Mentouri Constantine 1,

8 Algérie.

$9 \quad{ }^{2}$ Ecole Normale Supérieure Assia Djebar Constantine, Ville Universitaire Ali Mendjeli

10 Constantine, Algérie.

$11{ }^{3}$ UMR CNRS No. 6226, Institut des Sciences Chimiques de Rennes, ENSCR, 11 Allée de Beaulieu, CS 50837, 35708 Rennes Cedex 7, France

* Corresponding author. Tel.: +2136615758 52

E-mail address: bouzidi_henia@yahoo.fr(Hénia Bouzidi Mousser)

Abstract

The reaction of substitution of carbon monoxide by $\mathrm{P}(\mathrm{OMe})_{3}$ in the complex $(\mu$ $\left.\eta^{2} \mathrm{PhC}(\mathrm{S})=\mathrm{C}(\mathrm{S}) \mathrm{Ph}\right) \mathrm{Fe}_{2}(\mathrm{CO})_{6} \mathrm{1}$ under thermal activation afforded two colored compounds: a binuclear disubstituted complex $\quad(\mu-\mathrm{PhC}(\mathrm{S})=\mathrm{C}(\mathrm{S}) \mathrm{Ph}) \mathrm{Fe}_{2}(\mathrm{CO})_{4}\left[\mathrm{P}(\mathrm{OMe})_{3}\right]_{2} \quad \boldsymbol{2} \quad$ and $\quad$ a mononuclear iron disubstituted complex $\left(\eta^{2} \mathrm{PhC}(\mathrm{S})=\mathrm{C}(\mathrm{S}) \mathrm{Ph}\right) \mathrm{Fe}(\mathrm{CO})\left[\mathrm{P}(\mathrm{OMe})_{3}\right]_{2}$ 3. Mass spectrometry, ${ }^{1} \mathrm{H}$ NMR, IR and electrochemical studies established that two (CO) have been substituted by $\mathrm{P}(\mathrm{OMe})_{3}$ in complexes 2 and 3 . The $\mathrm{X}$-ray studies show that the two $\mathrm{P}(\mathrm{OMe})_{3}$ 


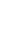

ligands are in apical positions in trans of the iron - iron bound of complex $\mathbf{2}$ and in equatorial positions in complex 3. However, the substitution reaction of $(\mathrm{CO})$ by $\mathrm{P}(\mathrm{OMe})_{3}$ in complex 1 under electron transfer catalysis (ETC) led to the monosubstituted compound $(\mu-$ $\mathrm{PhC}(\mathrm{S})=\mathrm{C}(\mathrm{S}) \mathrm{Ph}) \mathrm{Fe}_{2}(\mathrm{CO})_{5}\left[\mathrm{P}(\mathrm{OMe})_{3}\right] 4$.

Keywords: [FeFe] hydrogenase; Carbon monoxide substitution; Diiron hexacarbonyl complex; Thermal activation; Electron transfer catalysis; Single-crystal X-ray study

\section{Introduction}

Among vital hydrogenase enzymes, $[\mathrm{FeFe}]$ hydrogenases are receiving a special attention, due to their unusual structures and their catalytic power in production of hydrogen. The crystal structure of the [FeFe] hydrogenase was first reported in 1998 by Peters et al. [1] and later by Nicolet et al [2]. The binuclear complexes of iron whose structures are close to those of the [FeFe] hydrogenase complexes have been known for more than 80 years [3]. Since [FeFe] hydrogenase crystal structure publication [1], some complexes containing a Fe2S2 core have attracted the interest of chemists [4-8]. These complexes are easily synthesized and have been studied as structural and functional mimics of enzyme active site [9]. The catalytic properties for hydrogen generation by models of [FeFe] hydrogenases can be modified by substitution of one or two (CO) by more donor ligands in order to increase the electron density at the iron atoms enhancing its basicity. This substitution reactions can be carried out under thermal activation [10,11], photochemical activation [12,13] and Electron Transfer Catalysis (ETC) or electrochemical activation $[14,15]$ and is of major importance in organometallic and coordination chemistry in connection with catalytic processes. 
1 The carbon monoxide substitution by a ligand L more donor than $(\mathrm{CO})$ has been largely

2 investigated in iron polynuclear complexes [16-27]. Binuclear compounds $\left(\mu-\eta^{2}-\mathrm{ROCS}\right)(\mu-$

$3 \mathrm{SMe} \mathrm{Fe}_{2}(\mathrm{CO})_{6}[16]$ and $\left[(\mu-\mathrm{RS})_{2} \mathrm{Fe}_{2}(\mathrm{CO})_{6}\right][25]$ reacted with $\mathrm{P}(\mathrm{OMe})_{3}$ under ETC activation

4 to afford monosubstituted compounds firstly and then the disubstituted products $[17,18,28]$.

5 The results are apparently consistent with the empirical rule that one (CO) substitution occurs

6 at each metal centre [29]. However kinetic studies [30] and sequential use of $\mathrm{P}(\mathrm{OMe})_{3}$ and

$7 \quad \mathrm{P}\left(\mathrm{OCD}_{3}\right)_{3}[31]$ have revealed that the participation of bridging ligands does not be neglected

8 and the second (CO) substitution may be not exclusively on the unsubstituted metal center.

9 Under thermal activation, Lagadec et al. [32] studied the (CO) substitution in the binuclear complexes $[\mathrm{R} 1 \mathrm{C}(\mathrm{S}) \mathrm{SR} 2] \mathrm{Fe}_{2}(\mathrm{CO})_{6}$ and established that, with ligands such as $\mathrm{L}=\mathrm{P}(\mathrm{OMe})_{3}$, CNR or $\mathrm{PHPh}_{2}$, monosubstituted products were exclusively obtained. For all carbon monoxide substitutions by trimethyl phosphate in diiron hexacarbonyl complexes carried out under thermal or electron transfer catalysis activations [23], the same monosubstitution regioselectivity was observed in each case. Binuclear iron complexes with sulfured organic bridges are generally stable during their thermal reaction with ligands more donor than $(\mathrm{CO})$ $[27,33]$. Surprisingly, we have observed an unusual Fe-Fe bond cleavage in the complex $(\mu-$ $\left.\eta^{2} \mathrm{PhC}(\mathrm{S})=\mathrm{C}(\mathrm{S}) \mathrm{Ph}\right) \mathrm{Fe}_{2}(\mathrm{CO})_{6} 1$ [34] during its thermal reaction with $\mathrm{P}(\mathrm{OMe})_{3}$.

This work is a part of aiming to perform substitution reactions of $(\mathrm{CO})$ by ligands more donor in iron complexes having close resemblance to the diiron unit of the $[\mathrm{FeFe}]$ hydrogenase under thermal and ETC activations. In complex 1 when $\mathrm{P}(\mathrm{OMe})_{3}$ was used in substitution under thermal activation two complexes $\mathbf{2}$ and $\mathbf{3}$ were obtained (Scheme 1). The X-ray studies show that the two $\mathrm{P}(\mathrm{OMe})_{3}$ are in apical positions in trans of the iron - iron bound in complex 2 and in equatorial positions in complex 3. However the ETC substitution reaction led to the monosubstituted compound 4 (Scheme 1) according with spectroscopy and electrochemical 
analysis. In order to understand these exchange ligand reactions, the electrochemical behavior of complexes 1, 2, 3 and $\mathbf{4}$ was investigated and the results are reported here. (1)

\section{Scheme 1}

\section{Experimental}

\subsection{Physical measurements}

(1)

${ }^{1} \mathrm{H}$ NMR spectra were recorded at $89.55 \mathrm{MHz}$, in $\mathrm{CDCl}_{3}$ with TMS as internal standard. Mass spectra were recorded with a Varian MAT 311 spectrophotometer at $70 \mathrm{eV}$ at CRMPO (Rennes, France). Elemental analyses were carried out by Service Central d'Analyse (Vernaison, France). The electrochemical experiments were carried out in a three - electrode thermostated cell with a PAR 362 potentiostat coupled to a Kipp and Zonem XY recorder. Pt micro disc and a saturated calomel electrode (SCE) were used as working and reference electrodes, respectively. Diffraction measurements of single crystals of complexes $\mathbf{2}$ and $\mathbf{3}$ were made at $293 \mathrm{~K}$ on a Kappa CCD diffractometer (Bruker AXS BV, 1997 - 2004) equipped with a graphite monochromatic using Mo K $\alpha$ radiation $(\lambda=0.71073 \AA$ Á). Crystal data collection reduction and refinement were accomplished with COLLECCT (Nonius, 1998), SCALEPACK and DENZO [35] programs. The structure was solved by SIR 2002 [36] and refined by using SHELXL-97 [37]. The hydrogen atoms were located in Fourier maps but introduced in calculated positions and treated as riding on their parent $\mathrm{C}$ atom, with 0.95 (aromatic) and with $\operatorname{Uiso}(\mathrm{H})=1.2 \mathrm{Ueq}$ (aromatic $\mathrm{C}$ atoms). The molecular graphical was showed with ORTEP - 3 [38] program and material for publication was prepared with WinGX 1.7 software $[39,40]$. 
4 The supporting electrolyte $\mathrm{Bu}_{4} \mathrm{NBF}_{4}$ (Fluka, Purum) was recrystallized in a mixture of 5 methanol and water $(1 / 1)$, dried at $120^{\circ} \mathrm{C}$ and used at $0.1 \mathrm{M}$ concentration. Diiron nonacarbonyl (Strem Chemical, 99\%), trimethylphosphite (Fluka, Purum, 97\%) and diphenylacetylene (Aldrich, 99\%) were used as received. Toluene, petroleum ether, ethanol,

$\mathrm{CH}_{2} \mathrm{Cl}_{2}$ and DMF (SDS, analytical grade) were stored over $4 \AA$ A molecular sieves before use.

\subsection{Preparations}

\subsubsection{Reaction of $\left(\mu-\eta^{2} \mathrm{PhC}(\mathrm{S})=\mathrm{C}(\mathrm{S}) \mathrm{Ph}\right) \mathrm{Fe}_{2}(\mathrm{CO})_{6} 1$ with $\mathrm{P}(\mathrm{OMe})_{3}$ under thermal activation}

Diiron hexacarbonyl compound 1 was prepared according to the literature [34]. $\mathrm{P}(\mathrm{OMe})_{3}(5$ mmol) was added to compound $1(1.5 \mathrm{mmol})$ in dry toluene $(20 \mathrm{ml})$. The mixture, in the dark and under nitrogen, was heated at $45^{\circ} \mathrm{C}$ for $1 \mathrm{~h}$. The progress of the reaction was followed by thin layer chromatography. The reaction products were separated by chromatography on thin layer of silica gel and elution with petroleum ether. The isolated complexes were: 2 (30\%) and $3(25 \%)$. They were purified by crystallization from ethanol solution. All yields are based on $\left(\mathrm{Ph}(\mathrm{CS})_{2} \mathrm{Ph}\right) \mathrm{Fe}_{2}(\mathrm{CO})_{6}$.

2.3.1.1. Complex 2. $(\mu-\mathrm{PhC}(\mathrm{S})=\mathrm{C}(\mathrm{S}) \mathrm{Ph}) \mathrm{Fe}_{2}(\mathrm{CO})_{4}\left[\mathrm{P}(\mathrm{OMe})_{3}\right]_{2}$, m.p. $137^{\circ} \mathrm{C} .{ }^{1} \mathrm{H} \mathrm{NMR} \delta$ : 7.2(m) ppm. IR(KBr): $v \mathrm{CO}=1920 ; 1930 ; 1950 ; 2020 \mathrm{~cm}^{-1}$. Mass spectrum: $\mathrm{M}^{+}$found 685.9329; $\mathrm{M}^{+}$calc. 685.9348. 
2.3.1.2. Complex 3. $\left(\eta^{2} \mathrm{PhC}(\mathrm{S})=\mathrm{C}(\mathrm{S}) \mathrm{Ph}\right) \mathrm{Fe}(\mathrm{CO})\left[\mathrm{P}(\mathrm{OMe})_{3}\right]_{2}$, m.p. $148^{\circ} \mathrm{C} .{ }^{1} \mathrm{H}$ NMR $\delta: 7.2(\mathrm{~m})$ ppm. IR(KBr): $v \mathrm{CO}=1950 \mathrm{~cm}^{-1}$. Mass spectrum: $\mathrm{M}^{+}$found $574.0071 ; \mathrm{M}^{+}$calc. 574.0100.

\subsubsection{Reaction of $\left(\mu-\eta^{2} \mathrm{PhC}(\mathrm{S})=\mathrm{C}(\mathrm{S}) \mathrm{Ph}\right) \mathrm{Fe}_{2}(\mathrm{CO})_{6} \mathrm{I}$ with $\mathrm{P}(\mathrm{OMe})_{3}$ under ETC}

$\mathrm{P}(\mathrm{OMe})_{3}(5 \mathrm{mmol})$ was added to complex diiron hexacarbonyl 1 [34] $(0.38 \mathrm{mmol})$ in $\mathrm{CH}_{2} \mathrm{Cl}_{2}$ $0.1 \mathrm{M} \mathrm{Bu} u_{4} N^{+} B F_{4}^{-}(25 \mathrm{ml})$, in the dark and under nitrogen. The electrolysis was carried out by holding the potential at $-0.85 \mathrm{~V}$ versus $\mathrm{SCE}$ and was stopped when the electrolyzing current dropped sharply and the change in current reached minimal. After filtration, evaporation of the solvent and chromatography on silica gel the complex 4 (70\%) was isolated and was purified by crystallization from ethanol solution.

2.3.2.1. Complex 4. $(\mu-\mathrm{PhC}(\mathrm{S})=\mathrm{C}(\mathrm{S}) \mathrm{Ph}) \mathrm{Fe}_{2}(\mathrm{CO})_{5} \mathrm{P}(\mathrm{OMe})_{3}$, m.p. $101{ }^{\circ} \mathrm{C} .{ }^{1} \mathrm{H}$ NMR $\delta: 7.2(\mathrm{~m})$ ppm. IR $\left(\mathrm{C}_{2} \mathrm{Cl}_{4}\right): v \mathrm{CO}=1950 ; 1990 ; 2000 ; 2060 \mathrm{~cm}^{-1}$. Mass spectrum: $\mathrm{M}^{+}$found 589.90017; $\mathrm{M}^{+}$calc. 589.90084.

\section{Results and discussion}

\subsection{Thermal reaction of 1 with $P(O M e)_{3}$}

Under thermal activation an excess of $\mathrm{P}(\mathrm{OMe})_{3}$ reacted with $\mathrm{Ph}(\mathrm{CS})_{2} \mathrm{PhFe}_{2}(\mathrm{CO})_{6} 1$ and afforded two colored compounds: 2 (30 \%) and 3 (25\%). Spectroscopic (Mass, $\left.{ }^{1} \mathrm{HNMR}, \mathrm{IR}\right)$ analysis showed that complex $\mathbf{2}$ was a disubstituted binuclear compound. The IR spectrum of 2 on $\mathrm{KBr}$ pellet displayed intense bands between 1920 and $2020 \mathrm{~cm}^{-1}$ which were assigned to the terminal carbonyl coordinated to iron atoms. Mass spectrometry confirmed the presence of two $\mathrm{P}(\mathrm{OMe})_{3}$ in the compound 2 . The aromatic proton resonance was assigned to the complex 
multiplet centered at $\delta 7.2 \mathrm{ppm}$. Compound 3 was a mononuclear complex carrying two $\mathrm{P}(\mathrm{OMe})_{3}$ ligands. The formation of complex 3 involves the occurrence of a fragmentation on the iron carbonyl complex 1 during its thermal reaction with $\mathrm{P}(\mathrm{OMe})_{3}$. In order to understand this reaction, we investigated the cyclic voltammetry of complex $\mathbf{1}$ in the presence of $\mathrm{P}(\mathrm{OMe})_{3}$ ligand. and the of complex 1 was performed.

\subsection{Reaction of 1 with $P(O M e)_{3}$ under ETC}

\subsubsection{Cyclic voltammetry of complex 1}

In $\mathrm{CH}_{2} \mathrm{Cl}_{2}$, at room temperature, complex 1 underwent one two-electron reversible reduction step and the reduction potential was observed at - $0.99 \mathrm{~V}$ versus SCE (Fig.1). However, the lability of 1 may be disclosed in the presence of a donor ligand. When a ligand $\mathrm{P}(\mathrm{OMe})_{3}$ was added into solution of $\mathbf{1}$, the cyclic voltammogram (Fig.1) showed the typical behavior of a (CO) substitution by $\mathrm{P}(\mathrm{OMe})_{3}$ catalyzed by electron transfer occurring at the cathode surface $[41,42]$. The cathodic peak C1 (Epc $=-0.90 \mathrm{~V}$ versus $\mathrm{SCE})$ of $\mathbf{1}$ decreased while a peak C2, corresponding to the superposition of two peaks, appeared at more negative potential $(\mathrm{Epc}=-$ $1.30 \mathrm{~V}$ versus $\mathrm{SCE}$ ) and indicated the formation of mono and disubstituted complexes.

\section{Fig. 1}

3.2.2. Electrolysis of complex 1 in the presence of $P(O M e)_{3}$

The addition of an excess of $\mathrm{P}(\mathrm{OMe})_{3}$ to a solution of $\mathbf{1}$ under ETC led to the monosubstituted complex 4. The electrolysis (45 min) was carried out at - $0.85 \mathrm{~V}$ versus $\mathrm{SCE}$, in the dark and under nitrogen atmosphere. The mixture was treated and separated by chromatography on 
1 silica gel. No fragmentation of the iron carbonyl complex 1 was observed and the expected

2 monosubstituted complex 4 (70\%) was isolated.

\subsubsection{Voltammetric studies}

5

6 To understand the mechanism substitution reaction, voltammetric studies of the complexes $\mathbf{2}$,

$7 \quad 3$ and $\mathbf{4}$ were performed.

a. Cyclic voltammetry of complex 2

Under $\mathrm{N}_{2}$ atmosphere complex 2 was reduced in $\mathrm{CH}_{2} \mathrm{Cl}_{2}$ solution in a single chemically where the chemical step may be the Fe-S bond cleavage leading to the anion $\mathbf{2}^{\mathbf{2 -}}$ according to the described reduction of $\left(\mu^{2}-\mathrm{SPhS}-\right)_{\mathrm{Fe}_{2}}(\mathrm{CO})_{6}$ with 2 equiv of electrons [43]. The chemical step of this mechanism is also reversible.

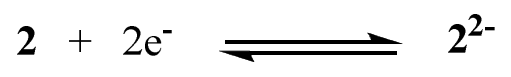

Under $\mathrm{CO}$ atmosphere, the dianion $\mathbf{2}^{\mathbf{2 -}}$ is not stable. The coordination of $(\mathrm{CO})$ induced replacement of the two $\mathrm{P}(\mathrm{OMe})_{3}$ ligands and at the reverse scan, voltammogram revealed the formation of the hexacarbonyl complex 1 (Fig.2, system $\mathrm{C}_{2} / \mathrm{A}_{2}$ ). At more negative potentials 20 an insertion of $(\mathrm{CO})$ on the dianion $\mathbf{2}^{2-}$ can lead, after $\mathrm{Fe}-\mathrm{Fe}$ bond cleavage, to an heptacarbonyl complex 5 (Scheme 2) whose oxidation is observed at - $0.5 \mathrm{~V}$ versus SCE (peak $\mathrm{A}_{3}$ ) according to an ECEC mechanism. 
$2 \quad$ Fig. 2

Scheme 2

5

b. Cyclic voltammetry of complex 3

Under $\mathrm{N}_{2}$ atmosphere complex 3 was reduced in $\mathrm{CH}_{2} \mathrm{Cl}_{2}$ solution in a single chemically reversible two-electron step (Fig.3, system $\mathrm{C}_{1} / \mathrm{A}_{1}$ ) at - $1.25 \mathrm{~V}$ versus $\mathrm{SCE}$ in comparison with

9 the intensity of the reduction current of the complex 1 . The obtained dianion $\mathbf{3}^{\mathbf{2 -}}$ was also

Scheme 3

Fig. 3

Under $\mathrm{CO}$ atmosphere, the voltammogram shows a high reactivity of the dianion $\mathbf{3}^{\mathbf{2 -}}$. Indeed, during the first potential scan a new reversible system $\mathrm{C}_{2} / \mathrm{A}_{2}$ appeared at $-0.9 \mathrm{~V}$ versus $\mathrm{SCE}$ assigned to tricarbonyl mononuclear complex 6 (Scheme 3) which oxidizes around $-0.5 \mathrm{~V}$ versus $\mathrm{SCE}$ (Fig.3, peak $\mathrm{A}_{3}$ ) according to an ECEC mechanism. 
Under $\mathrm{N}_{2}$ atmosphere the binuclear compound 4 was reduced in $\mathrm{CH}_{2} \mathrm{Cl}_{2}$ solution in a single chemically reversible two-electron step (Fig.4, peaks $\mathrm{C}_{1}$ and $\mathrm{A}_{1}$ ) observed at - $1.15 \mathrm{~V}$ versus SCE (Fig.4) in comparison with the intensity of the reduction current of the complex $\mathbf{1}$. These observations indicate that the dianion $\mathbf{4}^{2-}$ was stable and involved an ECE mechanism with a reversible chemical step where the chemical step may be the Fe-S bond cleavage.

$$
4+2 \mathrm{e}^{-} \rightleftharpoons 4^{2-}
$$

The difference between the reduction potentials of complexes $\mathbf{1}$ and $\mathbf{4}$ is about of $300 \mathrm{mV}$ and is in agreement with a monosubstitution of $(\mathrm{CO})$ by $\mathrm{P}(\mathrm{OMe})_{3}$.

Under $\mathrm{CO}$ atmosphere the voltammogram of 4 (Fig.4) showed that $\mathrm{P}(\mathrm{OMe})_{3}$ can be replaced by $(\mathrm{CO})$ after reduction of complex 4 into dianion $\mathbf{4}^{2-}$. During the reverse scan, two reversible systems $A_{2} / C_{2}$ and $A_{3} / C_{3}$ were observed at $-0.9 \mathrm{~V}$ and - 0.5 versus $\mathrm{SCE}$, respectively. $\mathrm{A}_{2} / \mathrm{C}_{2}$ was attributed to $\mathbf{1} / \mathbf{1}^{\mathbf{2}}$ system and $A_{3} / C_{3}$ may be assigned to the system $\mathbf{5} / \mathbf{5}^{\mathbf{2}}$ oxidation and reduction, according to the hypothesis that we have already formulated during the study of precedent complexes studies under CO atmosphere (Scheme 2).

\section{Fig. 4}

The structures of $\mathbf{2}$ and $\mathbf{3}$ were not clearly specified and an X-ray determination was needed to prove the proposed formulas in order to follow all the discussions on our results. However, 
1 the crystal structure of complex $\mathbf{4}$ could not be determined because of the poor quality of the

2 relevant crystals.

3.3. $X-$ Ray crystal analysis

3.3.1. X-Ray crystal analysis of compound 2

6

Crystals of complex $\mathbf{2}$ were triclinic with space group P-1. The X - Ray study of $\mathbf{2}$ established that it was a binuclear disubstituted complex. As expected, the molecular geometry of complex $\mathbf{2}$ is analogous to that of its parent arene dithiolate diiron complex $\mathbf{1}$. The molecular structure (Fig. 5) shows that one CO substitution occurs on each metal center, according to the empirical rule [29]. The two $\mathrm{P}(\mathrm{OMe})_{3}$ are in apical positions in trans of the iron - iron bound (Fig. 5). The Fe-Fe bound length $\left[2.4797(1) \AA ̊ d\right.$ is in accordance with that observed in $\left[\mathrm{Fe}_{2}(\mu-\right.$ btdt $\left.)(\mathrm{CO})_{4}\left(\mathrm{P}(\mathrm{OEt})_{3}\right)_{2}\right]$ complex [33] and is slightly shorter than that observed in the starting complex 1 [34]. The average Fe-P distances and Fe-Fe-P angles are $2.1703 \AA$ and $150.275^{\circ}$, respectively and are comparable to those observed for the selenium analogous complexes [44]. The average Fe-S-Fe angle and C-O distances of $65.94^{\circ}$ and $1.1469 \AA$ Á, respectively are in the same ranges of similar complexes [33]. The Fe-S bonds in 2 are slightly longer (ca. $0.0137 \AA$ ) than that in the unsubstituted compound 1 due to the stronger $\sigma$-donor properties of phosphite ligands compared to carbonyl groups [34]. Crystal data collection parameters and some of selected bond lengths and bond angles were given in Tables 1 and 2, respectively. In the crystal packing, the components of the structure are linked via intermolecular $\mathrm{C}-\mathrm{H}$.... and $\mathrm{C}-\mathrm{H}$....S hydrogen bonds (Table 3 ) to form a zigzag chain along the $a$-axis (Fig.6). 
1

Fig. 5
3

4

5

6

7

Collection parameters are shown in Table 1, and selected bond distances and angles are tabulated in Table 2.

\section{Table 1}

\section{Fig.6}

\section{Table 2}

\subsection{2. $X$ - ray crystal analysis of compound 3}

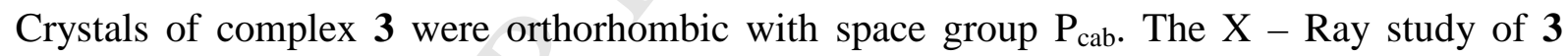
established that it was a mononuclear disubstituted iron complex with trigonal-bipyramidal geometry. The $\left[\mathrm{C}_{6} \mathrm{H}_{5} \mathrm{CS}\right]_{2}$ group was coordinated to the iron atom through the two $\mathrm{Fe}-\mathrm{S}$ bounds. The Fe $-\mathrm{S}$ bond lengths 2.1932(14) $\AA$ and 2.1523(13) $\AA$ are comparable to those observed for sulfur analogues [45] and were shorter than those obtained in complexes 1 [34] and 2. The dithio diphenylethylene groups were coordinated to the single iron with the two similar - $\mathrm{S}-\mathrm{C}(\mathrm{Ph})$ and the mean $(1.7315 \AA)$ of the $-\mathrm{S}-\mathrm{C}(\mathrm{Ph})$ bond lengths was shorter than that observed in complexes $\mathbf{1}$ [34] and 2. The P atoms were coordinated in an equatorial position with Fe-P bond lengths [2.1452(14) $\AA$ and 2.1220(14) $\AA$ ] and S-Fe-P angles [117.74(5) ${ }^{\circ}$, $144.05(5)^{\circ}, 89.04(5)^{\circ}$ and $\left.95.87(5)^{\circ}\right]$ are in accordance with those observed in similar 
complexes [45]. The coordination of the metal center was completed by one carbonyl in apical position $\left[170.56(16)^{\circ}\right]$. The $\mathrm{Fe}-\mathrm{CO}$ bond $(1.740(5) \AA)$ is slightly shorter than that observed in the complex 1 [34] and can be due to the $\pi$ back-donation of the iron atom towards the carbonyl [23]. $\mathrm{O} 2$ and $\mathrm{C} 2$ atoms of $\mathrm{P}(\mathrm{OMe})_{3}$ group present a severe disorder. The refined model using constraints corresponds to a distribution of these two atoms with 0.70 and 0.60 for $\mathrm{O} 2$ and $\mathrm{C} 2$ respectively (Fig. 7). Its crystal and collection parameters are shown in Table 1, and selected bond distances and angles are tabulated in Table 2. In the molecular stacking up of the complex $\mathbf{3}$, every two molecules are interpenetrated and linked via intermolecular $\mathrm{C}-\mathrm{H}$....O hydrogen bond (Table 3), forming a zigzag chain along the $b$ axis at $\mathrm{c}=0$ or $\mathrm{c}=1 / 2$ (Fig. 8). The double bond $\mathrm{PhC}(\mathrm{S})=\mathrm{C}(\mathrm{S}) \mathrm{Ph}(\mathrm{C} 5=\mathrm{C} 6$ of 1.3273 (5) $\AA$ ) in complex 2 is shorter than that observed in complex $3(\mathrm{C} 8=\mathrm{C} 9$ of 1.364 (6) $\AA$ ) and can be explained by a greater steric consideration in the complex 2 .

\section{Fig.7}

Fig.8

Table 3

\subsection{Proposed mechanism for the formation of complexes 2, 3 and $\mathbf{4}$}

The formation of $\mathbf{2 , 3}$ and $\mathbf{4}$ are summarized in the scheme 4 . However the mechanism of the reaction of complex 1 with an excess of $\mathrm{P}(\mathrm{OMe})_{3}$ could proceed according to a system 
composed of consecutive and competitive reactions. Thus the monosubstituted complex 4 is firstly formed, whatever the thermal [33] or E.T.C [46] activation. Starting from an excess of the $\mathrm{P}(\mathrm{OMe})_{3}$, under thermal activation, complex 4 could be involved in two competitive substitution reactions (Scheme 5). The first one would be a $(\mathrm{CO})$ exchange reaction consistent with the empirical rule that one (CO) substitution occurs at each metal center [29] leading to the complex 2 . The second (CO) substitution could occur on the same already substituted iron atom of $\mathbf{2}$ or $\mathbf{4}$ leading to a fragmentation resulting from the important steric effect and the resulting high charge density on this iron leading to the complex $3 . \mathrm{Fe}(\mathrm{CO})_{4}{ }^{2-}$ fragment could be formed as decomposition product of complexes 2 or 4 .

\section{Scheme 4}

\section{Scheme 5}

\section{Conclusion}

In this study, we have reported that exchange carbonyl reactions by $\mathrm{P}(\mathrm{OMe})_{3}$ in complex $(\mu-$ $\left.\eta^{2} \mathrm{PhC}(\mathrm{S})=\mathrm{C}(\mathrm{S}) \mathrm{Ph}\right) \mathrm{Fe}_{2}(\mathrm{CO})_{6} 1$ lead to three complexes, depending on the used activation. A binuclear disubstituted complex $(\mu-\mathrm{PhC}(\mathrm{S})=\mathrm{C}(\mathrm{S}) \mathrm{Ph}) \mathrm{Fe}_{2}(\mathrm{CO})_{4}\left[\mathrm{P}(\mathrm{OMe})_{3}\right]_{2}$ and a mononuclear iron disubstituted complex $\left(\eta^{2} \mathrm{PhC}(\mathrm{S})=\mathrm{C}(\mathrm{S}) \mathrm{Ph}\right) \mathrm{Fe}(\mathrm{CO})\left[\mathrm{P}(\mathrm{OMe})_{3}\right]_{2}$ were obtained under thermal activation. When using electron transfer catalysis the monosubstituted compound $(\mu-$ $\mathrm{PhC}(\mathrm{S})=\mathrm{C}(\mathrm{S}) \mathrm{Ph}) \mathrm{Fe}_{2}(\mathrm{CO})_{5}\left[\mathrm{P}(\mathrm{OMe})_{3}\right]$ was obtained. All the synthetized complexes were characterized by spectroscopic analysis (Mass, ${ }^{1} \mathrm{H}$ NMR, IR). Cyclic volammetry of complexes 1-4 were carried out and showed that they underwent in a single chemically reversible two-electron reduction step. Exchange of $\mathrm{CO}$ by $\mathrm{P}(\mathrm{OMe})_{3}$ induced by electron transfer were observed in the complex $\left(\mu-\eta^{2} \mathrm{PhC}(\mathrm{S})=\mathrm{C}(\mathrm{S}) \mathrm{Ph}\right) \mathrm{Fe}_{2}(\mathrm{CO})_{6}$. Under $\mathrm{CO}$ atmosphere 
$1 \mathrm{P}(\mathrm{OMe})_{3}$ were replaced by $\mathrm{CO}$ ligand in a chemical reversible step. The X-ray studies of ( $\mu$ -

$2 \quad \mathrm{PhC}(\mathrm{S})=\mathrm{C}(\mathrm{S}) \mathrm{Ph}) \mathrm{Fe}_{2}(\mathrm{CO})_{4}\left[\mathrm{P}(\mathrm{OMe})_{3}\right]_{2} \quad$ and $\quad\left(\eta^{2} \mathrm{PhC}(\mathrm{S})=\mathrm{C}(\mathrm{S}) \mathrm{Ph}\right) \mathrm{Fe}(\mathrm{CO})\left[\mathrm{P}(\mathrm{OMe})_{3}\right]_{2} \quad$ were

3 established and showed that the $\mathrm{P}(\mathrm{OMe})_{3}$ are in apical positions in the binuclear disubstituted

4 complex and are in equatorial positions in the mononuclear iron disubstituted complex.

5 Finally the exchange reaction of carbonyl by $\mathrm{P}(\mathrm{OMe})_{3}$ in the complex $(\mu$ -

$\left.6 \quad \eta^{2} \mathrm{PhC}(\mathrm{S})=\mathrm{C}(\mathrm{S}) \mathrm{Ph}\right) \mathrm{Fe}_{2}(\mathrm{CO})_{6}$ is not selective and the two ways (thermal activation and electron

7 transfer catalysis) did not lead to the same compounds.

9

\section{Formatting of funding sources}

This research did not receive any specific grant from funding agencies in the public, commercial, or not-for-profit sectors.

\section{Acknowledgements}

The authors express their thanks to the Algerian « Ministère de l'Enseignement Supérieur et de la Recherche Scientifique » and the Algerian «Direction Générale de la Recherche Scientifique et du Développement Technologique » for financial support.

\section{References}

[1] J.W. Peters, W.N. Lanzilotta, B.J. Lemon, L.C. Seefeldt, Science 282 (1998) 1853-1858.

[2] Y. Nicolet, C. Piras, P. Legrand, C.E. Hatchikian, J.C. Fontecilla-Camps, Structure 7 (1999) 13-23.

[3] H. Reihlen, A. Gruhl, G. V. Hessling, Justus Liebigs Ann. Chem. 472 (1929) 268-287.

[4] B.J. Petro, A.K. Vannucci, L.T. Lockett, C. Mebi, R. Kottani, N.E. Gruhn, G.S. Nichol, P.A.J. Goodyer, D.H. Evans, R.S. Glass, D.L. Lichtenberger, J. Mol. Struct. 890 (2008) 281288. 
1

2

3

4

5

[5] X.-F. Liu, Polyhedron 119 (2016) 71-76.

[6] J. Windhager, R. A. Seidel, U. P. Apfel, H. Görls, G. Linti, W. Weigand,Eur. J. Inorg. Chem. 10 (2008) 2023-2041.

[7] T. B. Rauchfuss, Acc. Chem. Res. 48, 7 (2015) 2107-2116.

[8] X. Yu, C.-H. Tung, W.G. Wang, M.T. Huynh, D.L. Gray, S. Hammes-Schiffer, T.B. Rauchfuss, Organometallics 36 (2017) 2245-2253.

[9] Y. Si, M. Hu, C. Chen, CR Chim. 11 (2008) 932-937.

[10] A. Rahaman, F.R. Alam, S. Ghosh, D.A. Tocher, M. Haukkae, S.E. Kabir, E. Nordlander, G. Hogarth, J. Organomet. Chem. 751 (2014) 326-335.

[11] J. He, C.-L. Deng, Y. Li, Y.-L. Li, Y. Wu, L.-K. Zou, Ch. Mu, Q. Luo, B. Xie, J. Wei, J.W. Hu, P.-H. Zhao, W. Zheng, Organometallics 36, 7 (2017) 1322-1330.

[12] B. Pfister, R. Stauber, A. Salzer, J. Organomet. Chem. 533 (1997) 131-141.

[13] P. H. Zhao, D. L. Gray, T. B. Rauchfuss, Eur. J. Inorg. Chem. (2016) 2681-2683.

[14] W. Jiang, Z. Li, X. Zeng, G. Wei, Asian J. Chem. 25, 14 (2013) 7655-7659.

[15] H. Hartmann, B. Sarkar, W. Kaim, J. Fielder, J. Organomet. Chem. 687 (2003) 100-107.

[16] A. Darchen, E. Lhadi, H. Patin, D. Grandjean, A. Mousser, J. Organomet. Chem. 385 (1990) C4-C8.

[17] A. Darchen, H. Mousser, H. Patin, J. Chem. Soc. Chem. Commun. (1988) 968-970.

[18] A. Darchen, E. Lhadi, H. Patin. J. Organomet. Chem. 259 (1983) 189-206.

[19] M. Natarajan, I.K. Pandey, S. Kaur-Ghumaan. Dalton Trans. DOI: 10.1039/C7DT01994G.

[20] W. Weia, T. Zheng, G. Zhao, G. Zeng, Z. Chi, L. Zhu, J. Organomet. Chem. 777, (2015) 67-70. 
1 [21] P. Zhao, X.-Y. Yu, X.-F. Liu, Y.-L. Li, Polyhedron 139 (2018) 116-124.

2 [22] Y.-D. Sheng, X.-Y. Yu, X.-F. Liu, Y.-L. Li, Polyhedron 137 (2017) 134-139.

3 [23] E. K.Lhadi, C. Mahe, H. Patin, A. Darchen, J. Organomet. Chem. 246, 2 (1983) C614 C64.

5 [24] L.-C. Song, W. Gao, X. Luo, Z.-X. Wang, X.-J. Sun, Hai-Bin Song, Organometallics $6 \quad 31(2012) 3324-3332$.

7 [25] D. Seyferth, R.S. Henderson, Li-Cheng Song, G.B. Womack. J. Organomet. Chem. 292 8 (1985) 9-17.

9 [26] Y.-L. Li, Z.-Y. Ma, J. He, M.-Y. Hu, P.-H. Zhao. J. Organomet. Chem. 851 (2017) 1410 21.

[27] S. Ghosh, B. E. Sanchez, I. Richards, M. N. Haque, K. B. Holt, M. G. Richmond, G.

Hogarth. J. Organomet. Chem. 812 (2016) 274-258.

[28] H. Patin, A. Le Rouzic, E.K. Lhadi, A. Darchen, A. Mousser, D. Grandjean. J.

Organomet. Chem. 375 (1989) 101-114.

[29] M.I. Bruce, J.G. Matisons, B.K. Nicholson, M.L. Williams. J. Organomet. Chem. 236 (1982) C57-C60.

[30] A. Darchen, E. Lhadi, H. Patin. J. Organomet. Chem. 363 (1989) 137-149.

[31] A. Darchen, E. Lhadi, H. Patin. J. Organomet. Chem. 327 (1987) C37-C40.

[32] A. Lagadec, B. Misterkiewicz, H. Patin, A. Mousser, J.Y. Le Marouille. J. Organomet. Chem. 315 (1986) 201-210.

[33] G. Durgaprasad, S.K. Das. J. Organomet. Chem. 717 (2012) 29-40. 
1 [34] H. Mousser, A. Darchen, A. Mousser. J. Organomet. Chem. 695 (2010) 786-791.

2 [35] Z. Otwinowski, W. Minor, in: C.W. Carter, R.M. Sweet (Eds.), Methods in Enzymology.

3 Macromolecular Crystallography. Part A, Vol. 276, Academic Press, New York, 1997, pp.

$4 \quad 307-326$.

5 [36] M.C. Burla, M. Camalli, B. Carrozzini, G.L. Cascarano, C. Giacovazzo, G. Polidori, R.

$6 \quad$ Spagna. J. Appl. Crystallogr. 36 (2003) 1103.

7 [37] G.M. Sheldrick, SHELXL-97, Programs for Crystal Structure Analysis (Release 97-2),

8 University of Göttingen, Germany, 1997.

9

[38] M.N. Burnette, C.K. Johnson, ORTEP III, Report ORNL-6895, Oak Ridge National Laboratory. Tennessee. USA, 1996.

[39] L.J. Farrugia, J. Appl. Crystallogr. 30 (1997) 565.

[40] L.J. Farrugia, J. Appl. Crystallogr. 32 (1999) 837-838.

[41] A.J. Downard, B.H. Robinson, J. Simpson, Organometalics 5 (1986) 1132-1140.

[42] H.H. Ohst, J.K. Kochi, Inorg. Chem. 25 (1986) 2066-2074.

[43] J.S. McKennis, E.P. Kyba, Organometallic 2 (1983) 1249-1251.

[44] M.K. Harb, J. Windhager, A. Daraosheh, H. Görls, L.T. Lockett, N. Okumura, D.H. Evans, R.S. Glass, D.L. Lichtenberger, M. El-khateeb, W. Weigand. Eur. J. Inorg. Chem (2009) 3414-3420.

[45] A. Orthaber, M. Karnahl, S. Tschierlei, D. Streich, M. Stein, S. Ott. Dalton Trans. 43 (2014) 4537-4549.

[46] A. Darchen, E.K. Lhadi, D. Grandjean, A. Mousser, H. Patin, J. Organomet. Chem. 342 (1988) C15-C19. 


\section{ACCEPTED MANUSCRIPT}

Table 1 Crystal data and refinement details for X-ray structure determination of complexes 2 and $\mathbf{3}$

\begin{tabular}{|c|c|c|}
\hline & Complex 2 & Complex $\mathbf{3}$ \\
\hline Molecular formula & $\mathrm{C}_{24} \mathrm{H}_{28} \mathrm{Fe}_{2} \mathrm{O}_{10} \mathrm{P}_{2} \mathrm{~S}_{2}$ & $\mathrm{C}_{21} \mathrm{H}_{28} \mathrm{FeO}_{7} \mathrm{P}_{2} \mathrm{~S}_{2}$ \\
\hline Formula weight $\left(\mathrm{g} \mathrm{mol}^{-1}\right)$ & 714,25 & 574,40 \\
\hline$T(K)$ & $293(2)$ & $293(2)$ \\
\hline Crystal system & Triclinic & Orthorhombic \\
\hline Space group & $\mathrm{P}-1$ & Pcab \\
\hline $\mathrm{a}(\hat{\AA})$ & $11.7332(6)$ & $13,0590(5)$ \\
\hline $\mathrm{b}(\hat{A})$ & $14.5531(6)$ & $14,7910(5)$ \\
\hline$c(\AA \hat{)})$ & $10.5775(6)$ & $27,4550(5)$ \\
\hline$\alpha\left({ }^{\circ}\right)$ & $103.35(5)$ & 90 \\
\hline$\beta\left({ }^{\circ}\right)$ & $101.02(3)$ & 90 \\
\hline$Y\left(^{\circ}\right)$ & $71.20(3)$ & 90 \\
\hline Volume $\left(\AA^{3}\right)$ & 1591.7 & $5303,09(29)$ \\
\hline Z & 2 & 8 \\
\hline Color & red & violet \\
\hline$\rho_{\text {cal }}\left(\mathrm{g} \mathrm{cm}^{-3}\right)$ & 1.490 & 1.440 \\
\hline$\mu\left(\mathrm{cm}^{-1}\right)$ & 11.91 & 8,84 \\
\hline$\theta_{\min }-\theta_{\max }$ & $1-25$ & $1.5-26.4$ \\
\hline Measured data & 5559 & 63108 \\
\hline Reflections used & 2304 & 5417 \\
\hline$F_{000}$ & 721.9 & 2382.7 \\
\hline Radiation & MoKa(Graphite Monochromated) & MoKa(Graphite Monochromated) \\
\hline Wave length (Á) & 0.71073 & 0.71073 \\
\hline No. data with $\mathrm{I}>2 \sigma$ & 3929 & 3595 \\
\hline number of parameters & 380 & 317 \\
\hline $\mathrm{R}_{\text {int }}$ & 0.040 & 0.0801 \\
\hline$R_{1}(I>2 \sigma)$ & 0.03446 & 0.0695 \\
\hline $\mathrm{wR}_{2}$ & 0.04570 & 0.1762 \\
\hline GOF & 1.614 & 1.077 \\
\hline
\end{tabular}


Table 2 Selected bond lengths $(\AA)$ and angles $\left(^{\circ}\right)$ in complexes $\mathbf{2}$ and $\mathbf{3}$

\begin{tabular}{|c|c|c|c|}
\hline Complex 2 & & Complex 3 & \\
\hline Bond lengths ( $(\dot{A})$ & & Bond lengths $(\grave{A})$ & \\
\hline $\mathrm{Fe}(1)-\mathrm{S}(1)$ & $2.2821(1)$ & $\mathrm{Fe}(1)-\mathrm{S}(1)$ & $2.1932(14)$ \\
\hline $\mathrm{Fe}(1)-\mathrm{S}(2)$ & $2.2771(1)$ & $\mathrm{Fe}(1)-\mathrm{S}(2)$ & $2.1523(13)$ \\
\hline $\mathrm{Fe}(1)-\mathrm{P}(1)$ & $2.1681(1)$ & $\mathrm{Fe}(1)-\mathrm{P}(1)$ & $2.1452(14)$ \\
\hline $\mathrm{Fe}(1)-\mathrm{C}(1)$ & $1.7545(1)$ & $\mathrm{Fe}(1)-\mathrm{C}(7)$ & $1.740(5)$ \\
\hline $\mathrm{Fe}(1)-\mathrm{C}(2)$ & $1.7659(3)$ & l & I \\
\hline$S(1)-C(5)$ & $1.8179(3)$ & $S(1)-C(8)$ & $1.727(4)$ \\
\hline$S(2)-C(6)$ & $1.8219(9)$ & $S(2)-C(9)$ & $1.736(4)$ \\
\hline$C(5)-C(6)$ & $1.3273(5)$ & $C(8)-C(9)$ & $1.364(6)$ \\
\hline I & I & $\mathrm{Fe}(1)-\mathrm{P}(2)$ & $2.1220(14)$ \\
\hline $\mathrm{Fe}(2)-\mathrm{S}(1)$ & $2.2921(1)$ & I & I \\
\hline $\mathrm{Fe}(2)-\mathrm{S}(2)$ & $2.2615(1)$ & I & I \\
\hline $\mathrm{Fe}(2)-\mathrm{P}(2)$ & $2.1725(1)$ & 1 & \\
\hline $\mathrm{Fe}(2)-\mathrm{C}(3)$ & $1.7643(3)$ & I & \\
\hline $\mathrm{Fe}(2)-\mathrm{C}(4)$ & $1.7651(13)$ & I & \\
\hline $\mathrm{Fe}(1)-\mathrm{Fe}(2)$ & $2.4797(1)$ & I & \\
\hline \multirow[t]{2}{*}{ Angles $\left({ }^{\circ}\right)$} & & Angles $\left({ }^{\circ}\right)$ & \\
\hline & & $\mathrm{S}(1)-\mathrm{Fe}(1)-\mathrm{S}(2)$ & $88.10(4)$ \\
\hline$S(1)-\mathrm{Fe}(1)-\mathrm{S}(2)$ & $78.95(1)$ & $S(1)-F e(1)-P(1)$ & $89.04(5)$ \\
\hline$S(1)-F e(1)-P(1)$ & $100.11(1)$ & $S(1)-F e(1)-P(2)$ & $95.87(5)$ \\
\hline ' & I & $\mathrm{S}(2)-\mathrm{Fe}(1)-\mathrm{C}(7)$ & $87.38(14)$ \\
\hline $\mathrm{S}(2)-\mathrm{Fe}(1)-\mathrm{C}(1)$ & $89.86(1)$ & $S(1)-\mathrm{Fe}(1)-\mathrm{C}(7)$ & $170.47(15)$ \\
\hline $\mathrm{S}(1)-\mathrm{Fe}(1)-\mathrm{C}(1)$ & $160.73(1)$ & $S(2)-F e(1)-P(1)$ & $144.05(5)$ \\
\hline$S(2)-F e(1)-P(1)$ & $103.77(2)$ & $S(1)-C(8)-C(9)$ & 119.1(3) \\
\hline$S(1)-C(5)-C(6)$ & $116.14(1)$ & $\mathrm{Fe}(1)-\mathrm{S}(1)-\mathrm{C}(8)$ & $106.66(15)$ \\
\hline $\mathrm{Fe}(1)-\mathrm{S}(1)-\mathrm{C}(5)$ & $101.98(1)$ & $\mathrm{Fe}(1)-\mathrm{S}(2)-\mathrm{C}(9)$ & $107.95(14)$ \\
\hline $\mathrm{Fe}(1)-\mathrm{S}(2)-\mathrm{C}(6)$ & $102.61(1)$ & $P(2)-F e(1)-P(1)$ & $98.20(5)$ \\
\hline I & 1 & $\mathrm{~S}(2)-\mathrm{Fe}(1)-\mathrm{P}(2)$ & $117.74(5)$ \\
\hline l & l & l & I \\
\hline $\mathrm{Fe}(2)-\mathrm{Fe}(1)-\mathrm{P}(1)$ & $150.57(1)$ & I & l \\
\hline $\mathrm{Fe}(1)-\mathrm{Fe}(2)-\mathrm{P}(2)$ & $149.98(1)$ & I & I \\
\hline$S(1)-\mathrm{Fe}(2)-\mathrm{S}(2)$ & $79.06(1)$ & I & I \\
\hline$S(1)-\mathrm{Fe}(2)-\mathrm{P}(2)$ & $103.59(2)$ & I & I \\
\hline $\mathrm{S}(2)-\mathrm{Fe}(2)-\mathrm{P}(2)$ & $99.31(1)$ & I & I \\
\hline $\mathrm{Fe}(2)-\mathrm{Fe}(1)-\mathrm{S}(1)$ & $57.37(1)$ & & \\
\hline $\mathrm{Fe}(2)-\mathrm{Fe}(1)-\mathrm{S}(2)$ & $56.58(1)$ & & \\
\hline
\end{tabular}




\section{ACCEPTED MANUSCRIPT}

Table 3 Hydrogen bonds $(\AA)$ and angles $\left(^{\circ}\right)$ in complexes 2 and 3

\begin{tabular}{llcccc}
\hline & D - H...A & D $-\mathbf{H}$ & H...A & D ...A & D - H...A \\
\hline Complex 2 & $\mathrm{C} 11-\mathrm{H} 4 \ldots 5^{(\text {(I) }}$ & 0.99 & 2.36 & $3.261(2)$ & 148 \\
& $\mathrm{C} 9-\mathrm{H} 2 \ldots \mathrm{S} 2^{(\mathrm{ii})}$ & 1 & 2.99 & $3.246(6)$ & 176 \\
Complex 3 & $\mathrm{C} 19-\mathrm{H} 19 \ldots 7^{(\text {iii) }}$ & 0.93 & 2.62 & $3.993(3)$ & 125 \\
& & & & & \\
\hline
\end{tabular}

Symmetry codes: (i) $-\mathrm{x}+1,-\mathrm{y}+1,-\mathrm{z}+1$; (ii) $-\mathrm{x},-\mathrm{y}+1,-\mathrm{z}+1$. (iii) $\mathrm{x}, \mathrm{y}-1 / 2,-\mathrm{z}+1 / 2$. 


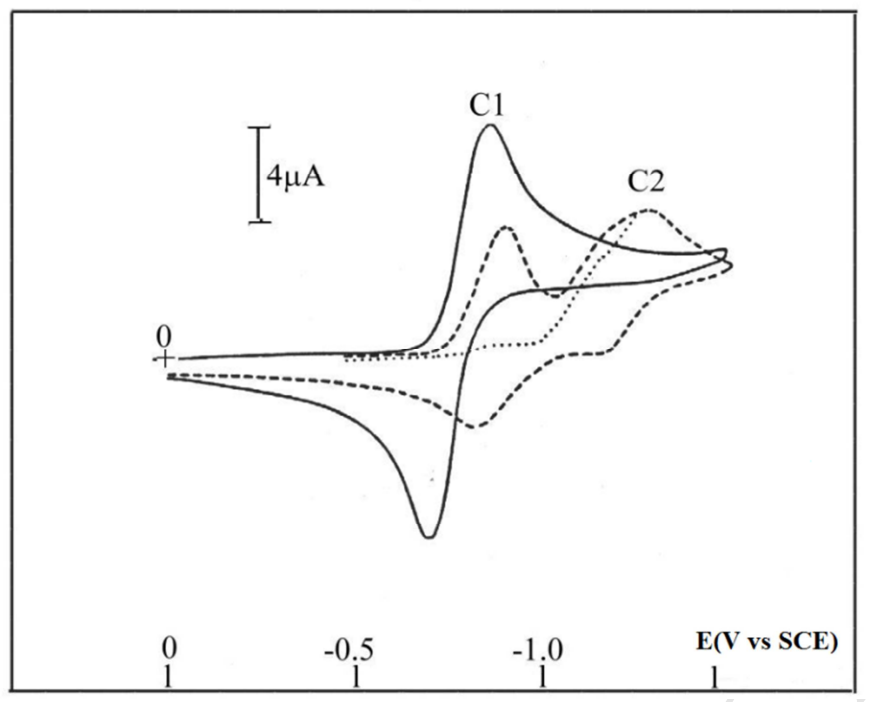

Fig.1. Cyclic voltammetry of $2 \mathrm{mM}$ of complex 1 in $\mathrm{CH}_{2} \mathrm{Cl}_{2} 0.1 \mathrm{M} \mathrm{Bu}_{4} \mathrm{~N}^{+} \mathrm{BF}_{4}{ }^{-}$; Pt electrode; scan rate $0.1 \mathrm{Vs}^{-1}$. Complex 1 alone; and First and second scan in the presence of an excess of $\mathrm{P}(\mathrm{OMe})_{3}$.

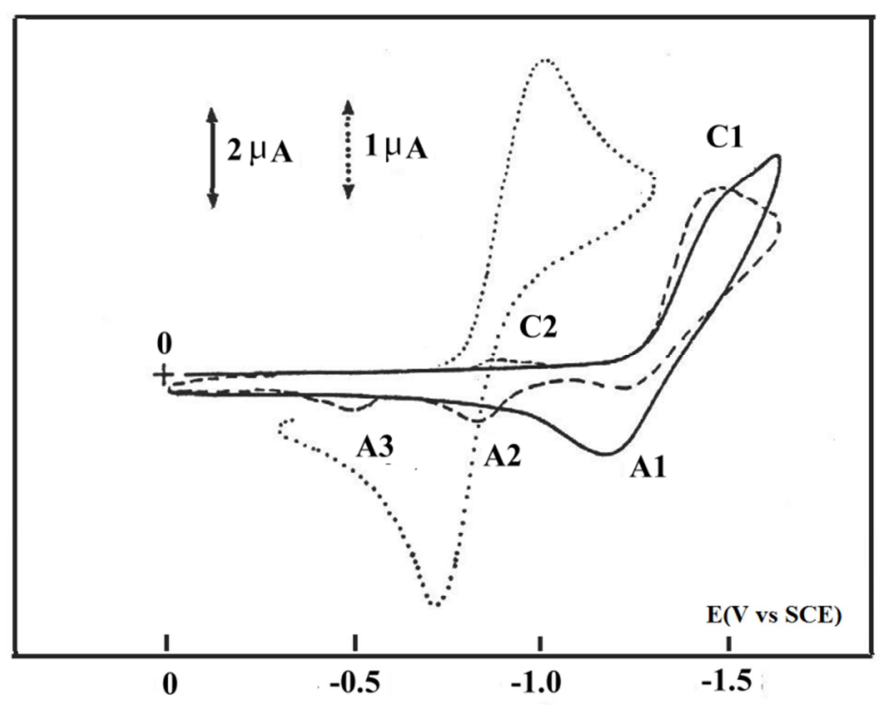

Fig.2. Cyclic voltammetry of $2 \mathrm{mM}$ of complex 2 in $\mathrm{CH}_{2} \mathrm{Cl}_{2} 0.1 \mathrm{M} \mathrm{Bu}_{4} \mathrm{~N}^{+} \mathrm{BF}_{4}{ }^{-}$; Pt electrode; scan rate $0.2 \mathrm{~V} \mathrm{~s}^{-1}$. Complex 2 under $\mathrm{N}_{2}$ atmosphere; Complex 2 under $\mathrm{CO}$ atmosphere.

Complex 1 (2 mM) under $\mathrm{N}_{2}$ atmosphere. 


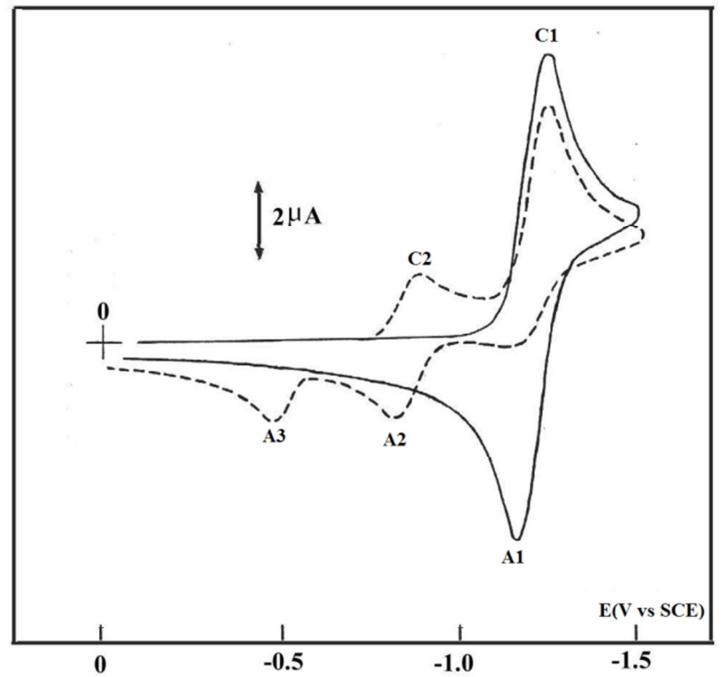

Fig.3. Cyclic voltammetry of $2 \mathrm{mM}$ of complex 3 in $\mathrm{CH}_{2} \mathrm{Cl}_{2} 0.1 \mathrm{M} \mathrm{Bu}_{4} \mathrm{~N}^{+} \mathrm{BF}_{4}{ }^{-}$; Pt electrode; scan rate $0.2 \mathrm{~V} \mathrm{~s}^{-1}$. Complex 3 under $\mathrm{N}_{2}$ atmosphere; Complex 3 under $\mathrm{CO}$ atmosphere.

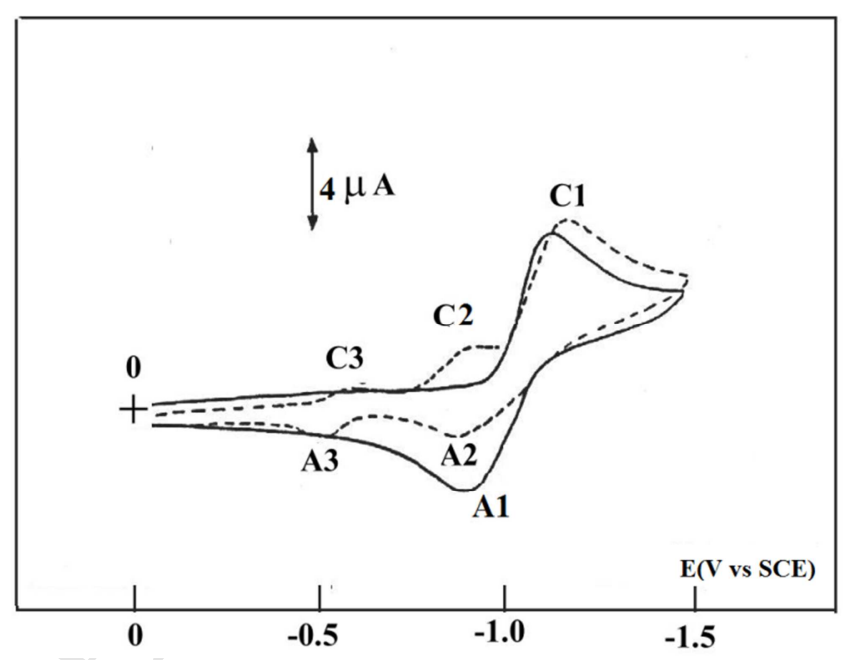

Fig.4. Cyclic voltammetry of $2 \mathrm{mM}$ of complex 4 in $\mathrm{CH}_{2} \mathrm{Cl}_{2} 0.1 \mathrm{M} \mathrm{Bu}_{4} \mathrm{~N}^{+} \mathrm{BF}_{4}{ }^{-}$; Pt electrode; scan rate $0.2 \mathrm{Vs}^{-1}$. _ Complex 4 under $\mathrm{N}_{2}$ atmosphere; ...... Complex 4 under $\mathrm{CO}$ atmosphere. 


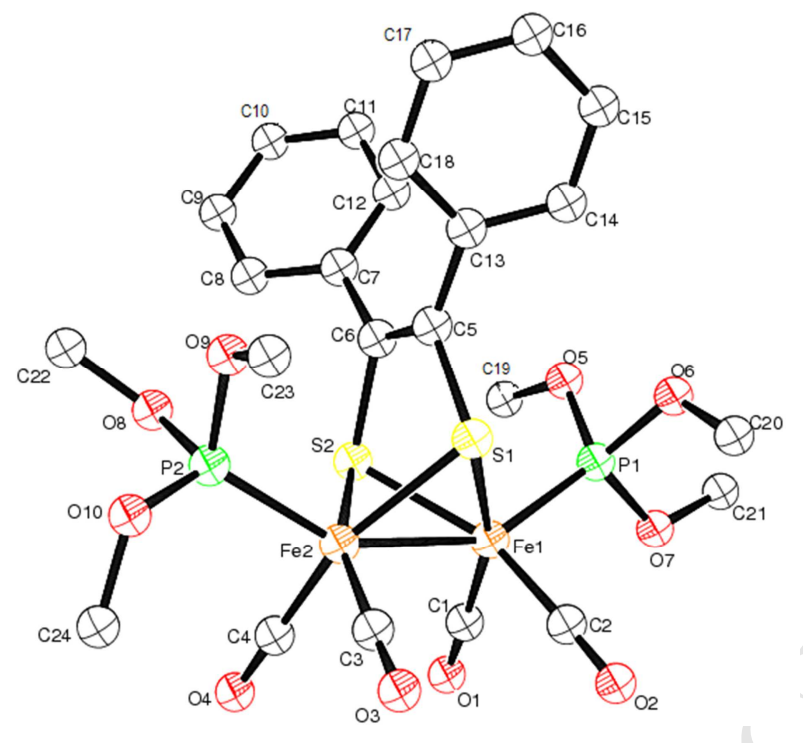

Fig.5. Molecular structure of complex 2 with thermal ellipsoids at 30\% probability. Hydrogen atoms are omitted for clarity.

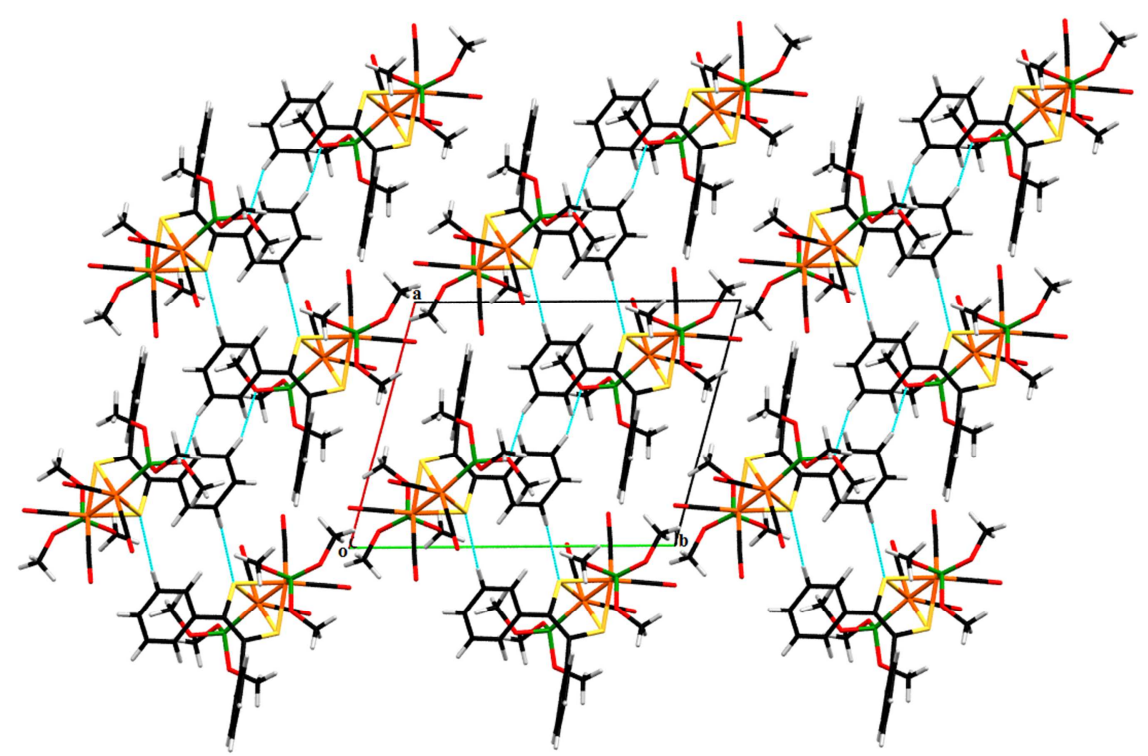

Fig.6. The crystal packing viewed along axis $c$. Dashed lines indicate intermolecular C- H...O and CH....S hydrogen bonds which join molecules into endless chains along the $\boldsymbol{a}$-axis direction. 


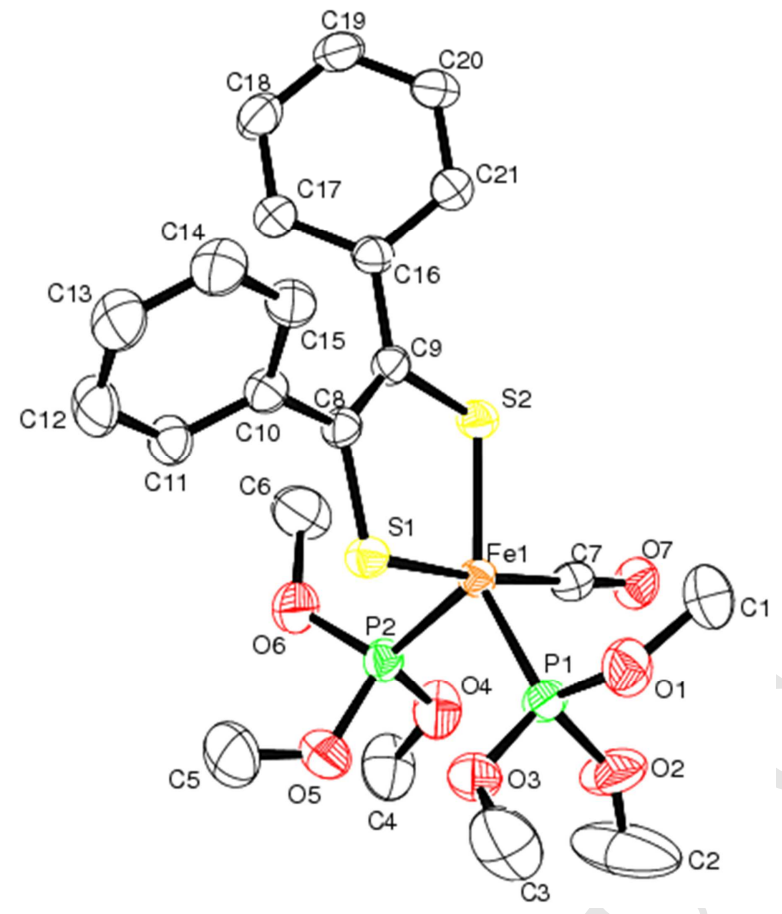

Fig.7. Molecular structure of complex $\mathbf{3}$ with thermal ellipsoids at 30\% probability. Hydrogen atoms are omitted for clarity.

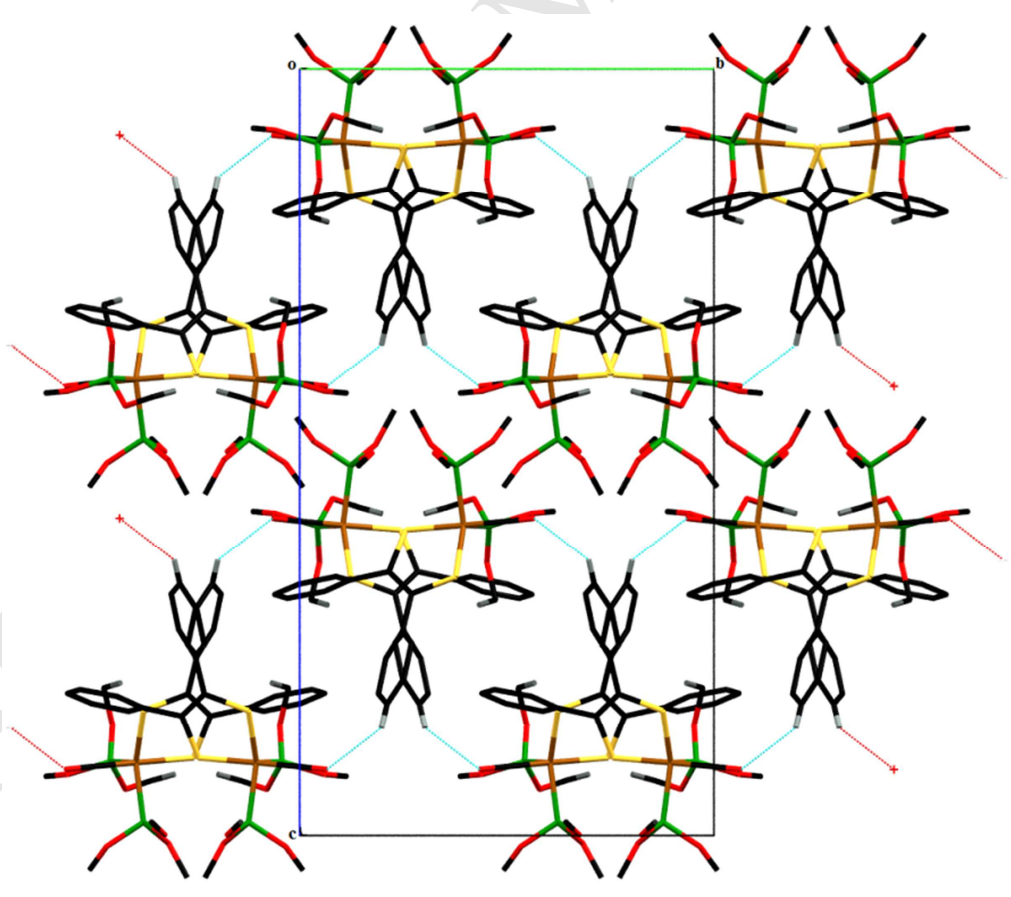

Fig.8. The crystal packing viewed along axis a. Dashed lines indicate C-H...O intermolecular hydrogen bond, forming a zigzag chain along the $b$ axis at $\mathrm{c}=0$ and $\mathrm{c}=1 / 2$. 


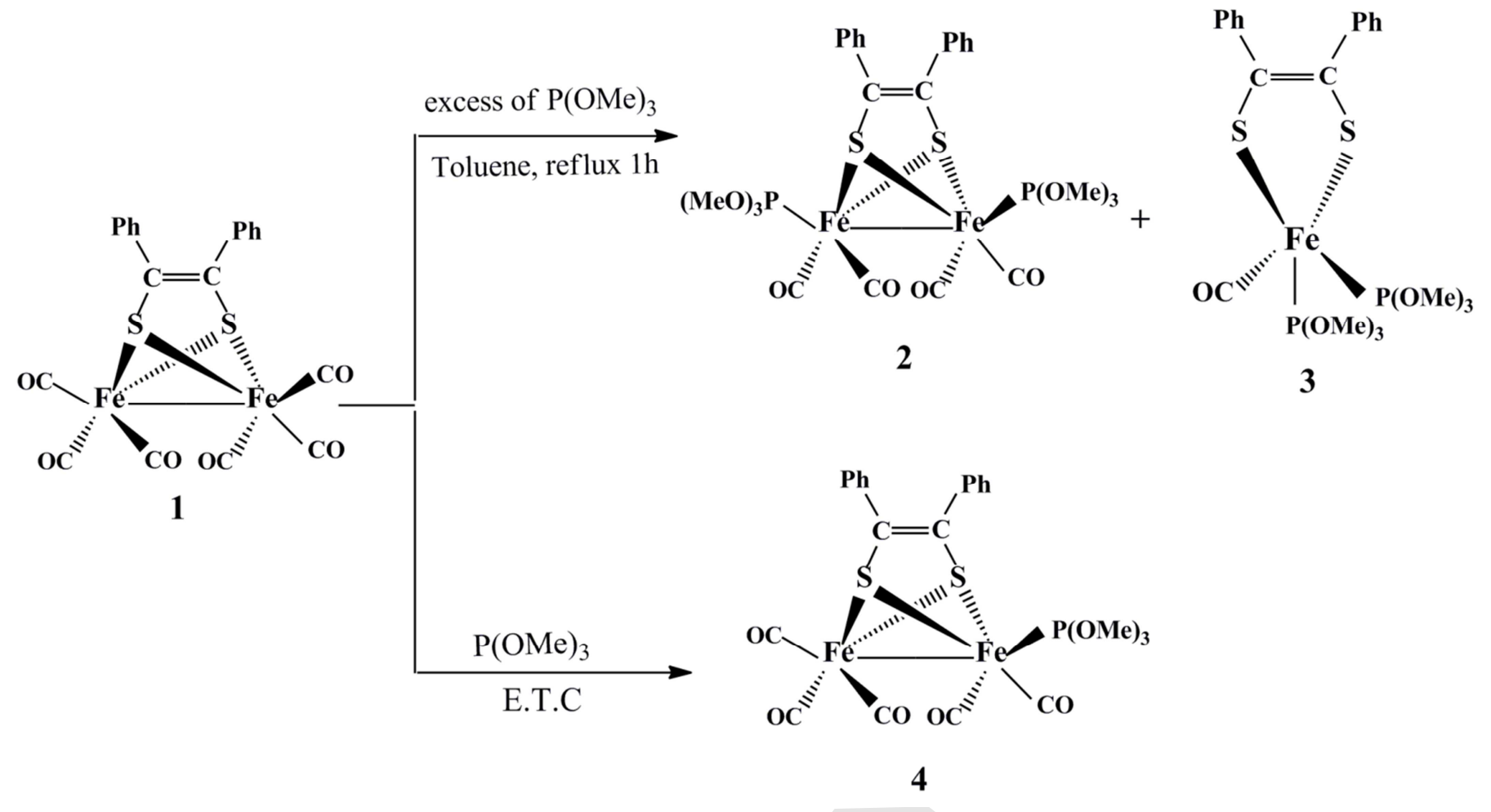

Scheme 1. Reaction under thermal and ETC activations

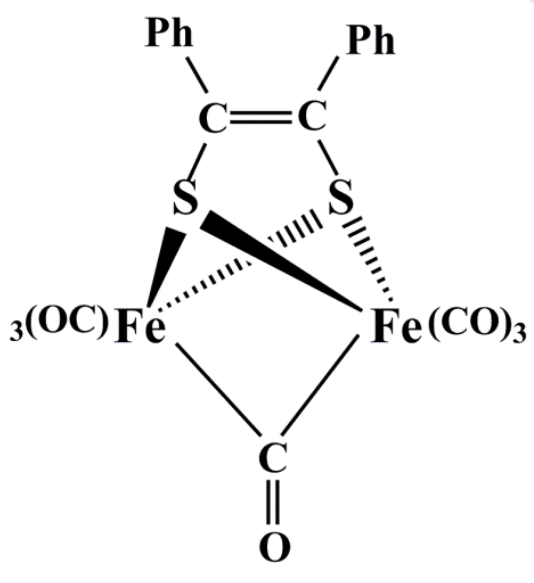

Scheme 2. Complex 5

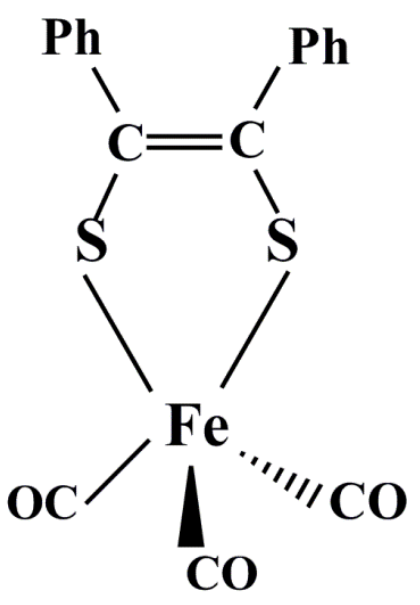

Scheme 3. Complex 6 


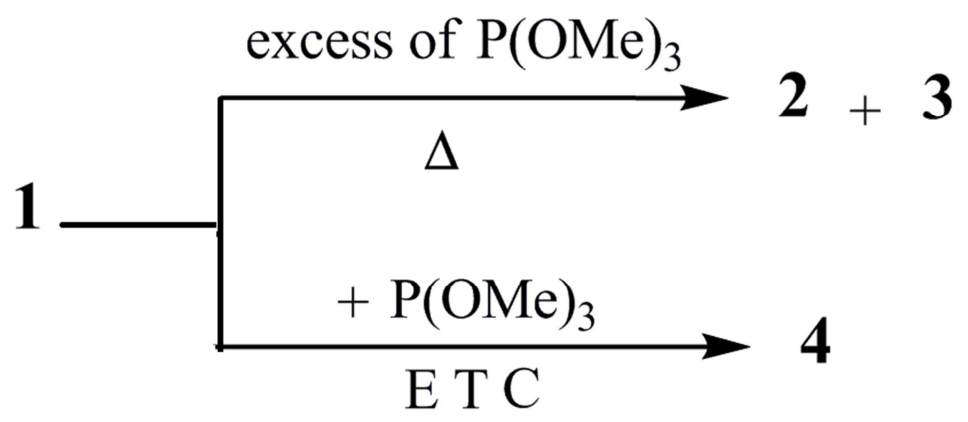

Scheme 4. Reactions of complex 1 with $\mathrm{P}(\mathrm{OMe})_{3}$ under ETC and thermal activations

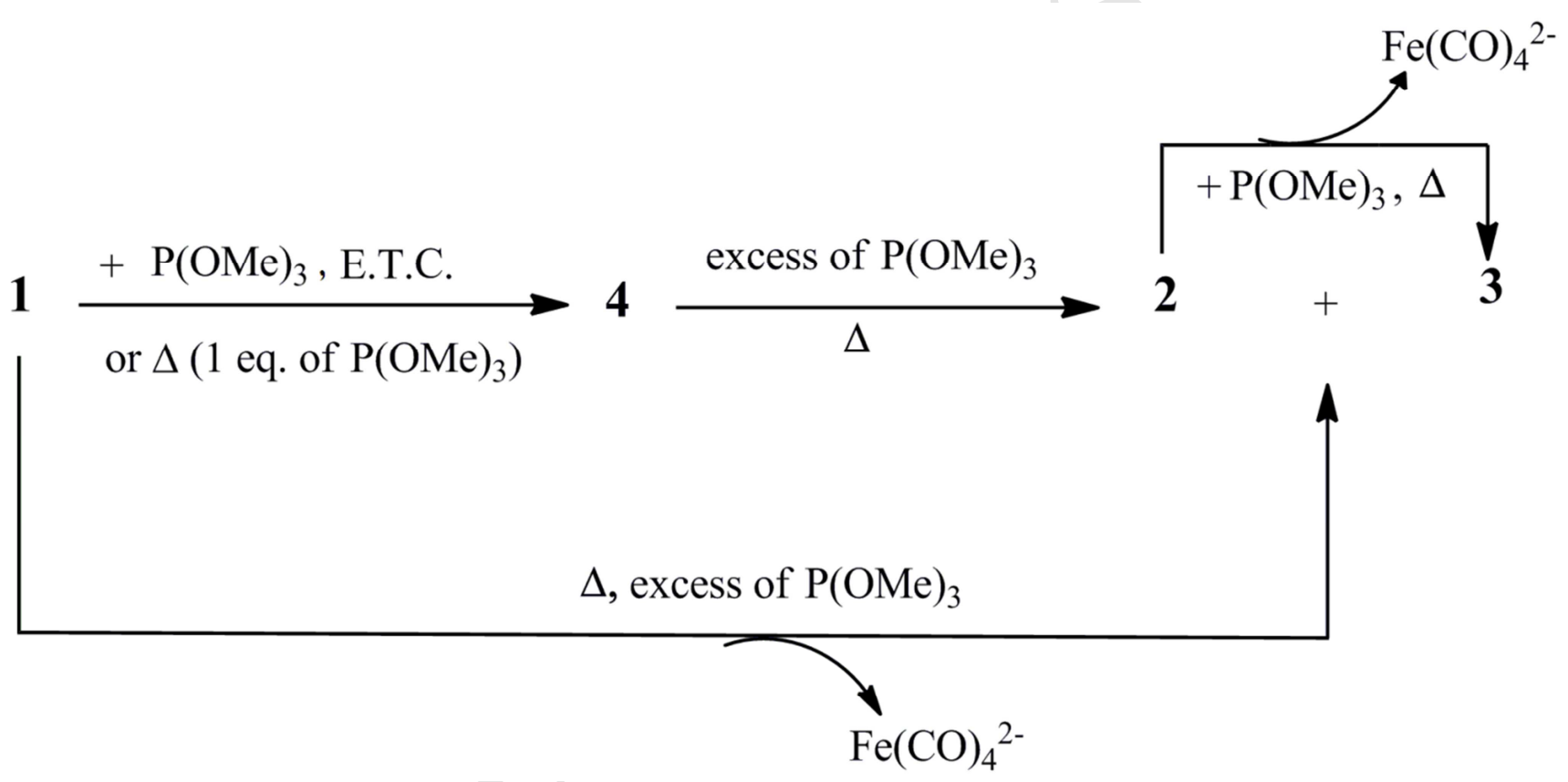

Scheme 5. Proposed mechanism of reaction of 1 with $\mathrm{P}(\mathrm{OMe})_{3}$ 
- Carbonyl exchange by $\mathrm{P}(\mathrm{OMe})_{3}$ in $\left(\mu-\eta^{2} \mathrm{PhC}(\mathrm{S})=\mathrm{C}(\mathrm{S}) \mathrm{Ph}\right) \mathrm{Fe}_{2}(\mathrm{CO})_{6}$ lead to three complexes

- Thermal activation lead to a binuclear and a mononuclear iron disubstituted complexes

- Under electron transfer catalysis a binuclear monosubstituted complex was obtained

- Complexes volammetry showed a chemical two electrons reversible reduction step

- When $\mathrm{P}(\mathrm{OMe})_{3}$ was added $\mathrm{CO}$ substitutions were induced by electron transfer catalysis 